\title{
Dramatic increase in reactive volatile organic compound (VOC) emissions from ships at berth after implementing the fuel switch policy in the Pearl River Delta Emission Control Area
}

\author{
Zhenfeng Wu ${ }^{1,3}$, Yanli Zhang ${ }^{1,2}$, Junjie He ${ }^{4}$, Hongzhan Chen ${ }^{4}$, Xueliang Huang ${ }^{1,5}$, Yujun Wang ${ }^{4}, \mathbf{X u ~ Y u}^{1,3}$, \\ Weiqiang Yang ${ }^{1,3}$, Runqi Zhang ${ }^{1,3}$, Ming Zhu ${ }^{1,3}$, Sheng $\mathbf{L i}^{1,3}$, Hua Fang ${ }^{1,3}$, Zhou Zhang ${ }^{6}$, and Xinming Wang ${ }^{1,2,3}$ \\ ${ }^{1}$ State Key Laboratory of Organic Geochemistry and Guangdong Key Laboratory of Environmental Protection and Resources \\ Utilization, Guangzhou Institute of Geochemistry, Chinese Academy of Sciences, Guangzhou 510640, China \\ ${ }^{2}$ Center for Excellence in Regional Atmospheric Environment, Institute of Urban Environment, \\ Chinese Academy of Sciences, Xiamen 361021, China \\ ${ }^{3}$ University of Chinese Academy of Sciences, Beijing 100049, China \\ ${ }^{4}$ Guangzhou Environmental Monitoring Center, Guangzhou 510640, China \\ ${ }^{5}$ Yunfu Total Pollutant Discharge Control Center, Yunfu 527300, China \\ ${ }^{6}$ Changsha Center for Mineral Resources Exploration, Guangzhou Institute of Geochemistry, \\ Chinese Academy of Sciences, Changsha 410013, China
}

Correspondence: Yanli Zhang (zhang_yl86@gig.ac.cn)

Received: 4 October 2019 - Discussion started: 29 October 2019

Revised: 26 December 2019 - Accepted: 22 January 2020 - Published: 19 February 2020

\begin{abstract}
Limiting fuel sulfur content (FSC) is a widely adopted approach for reducing ship emissions of sulfur dioxide $\left(\mathrm{SO}_{2}\right)$ and particulate matter (PM), particularly in emission control areas (ECAs), but its impact on the emissions of volatile organic compounds (VOCs) is still not well understood. In this study, emissions from ships at berth in Guangzhou, southern China, were characterized before and after the implementation of the fuel switch policy (IFSP) with an FSC limit of $0.5 \%$ in the Pearl River Delta ECA (ECA-PRD). After IFSP, the emission factors (EFs) of $\mathrm{SO}_{2}$ and $\mathrm{PM}_{2.5}$ for the coastal vessels decreased by $78 \%$ and $56 \%$ on average, respectively; however, the EFs of the VOCs were $1807 \pm 1746 \mathrm{mg} \mathrm{kg}^{-1}$, approximately 15 times that of $118 \pm 56.1 \mathrm{mg} \mathrm{kg}^{-1}$ before IFSP. This dramatic increase in the emissions of the VOCs might have been largely due to the replacement of high-sulfur residual fuel oil with low-sulfur diesel or heavy oils, which are typically richer in short-chain hydrocarbons. Moreover, reactive alkenes surpassed alkanes to become the dominant group among the VOCs, and lowcarbon-number VOCs, such as ethylene, propene and isobutane, became the dominant species after IFSP. As a result of the largely elevated EFs of the reactive alkenes and aromatics
\end{abstract}

after IFSP, the emitted VOCs per kilogram of fuel burned had nearly 29 times greater ozone formation potential (OFP) and approximately 2 times greater secondary organic aerosol formation potential (SOAFP) than those before IFSP. Unlike the coastal vessels, the river vessels in the region used diesel fuels consistently and were not affected by the fuel switch policy, but the EFs of their VOCs were $90 \%$ greater than those of the coastal vessels after IFSP, with approximately $120 \%$ greater fuel-based OFP and $70 \%-140 \%$ greater SOAFP. The results from this study suggest that while the fuel switch policy could effectively reduce $\mathrm{SO}_{2}$ and $\mathrm{PM}$ emissions, and thus help control $\mathrm{PM}_{2.5}$ pollution, it will also lead to greater emissions of reactive VOCs, which may threaten ozone pollution control in harbor cities. This change for coastal or oceangoing vessels, in addition to the large amounts of reactive VOCs from the river vessels, raises regulatory concerns for ship emissions of reactive VOCs. 


\section{Introduction}

World seaborne trade volumes are estimated to account for over $80 \%$ of the total global merchandise trade (UNCTAD, 2016). The controls on ship emissions, however, are far less stringent than those on land emissions sources, and, unsurprisingly, ship engines are among the world's highest polluting combustion sources in terms of per tonne of fuel consumed (Corbett and Fischbeck, 1997). As a large amount of marine ship emissions occur within $400 \mathrm{~km}$ of coastlines (Fu et al., 2017), ship emissions can cause air pollution in coastal areas and thus contribute substantially to the environmental burden of disease (Corbett et al., 2007; Lv et al., 2018; Feng et al., 2019; Ramacher et al., 2019; X. Wang et al., 2019). Therefore, global efforts have been implemented to regulate and prevent health risks from ship emissions particularly in harbor cities.

An important intervention policy by the International Maritime Organization (IMO) to reduce ship emissions is the designation of emission control areas (ECAs) where a more stringent limit of fuel sulfur content (FSC) is implemented (IMO, 2017). This ECA approach has resulted in significant improvements in ambient air quality for coastal areas (Lack et al., 2011; Tao et al., 2013; Contini et al., 2015; Zetterdahl et al., 2016). In the North Sea, for example, the new policy restricting FSC below $1.5 \%$ since 2007 has resulted in reduction rates of $42 \%, 38 \%$ and $20 \%$ for ambient concentrations of sulfur dioxide $\left(\mathrm{SO}_{2}\right)$, sulfate aerosols and ammonium aerosols, respectively, which were related to ship emissions (Matthias et al., 2010); monitoring in US coastal states has revealed significant reductions in ambient $\mathrm{PM}_{2.5}$ (particulate matter with an aerodynamic diameter less than $2.5 \mu \mathrm{m}$ ) from residual fuel oil (RFO) combustion due to marine vessel fuel sulfur regulations in the North American Emission Control Area (NA-ECA) (Kotchenruther, 2017). In the Marmara Sea and the Turkish Straits, ship emissions of $\mathrm{SO}_{2}, \mathrm{PM}_{2.5}$ and $\mathrm{PM}_{10}$ (particulate matter with an aerodynamic diameter less than $10 \mu \mathrm{m})$ were projected to be reduced by $95 \%$, $67 \%$ and $67 \%$, respectively, if FSC was restricted to below $0.1 \%$ (Viana et al., 2015). Consequently, with the increasingly stringent control over land-based emissions sources, limiting ship emissions has gradually stood out as an effective measure to control air pollution in coastal zones.

Intervention measures for ship emissions, however, are mostly targeted at $\mathrm{SO}_{2}$ and $\mathrm{PM}$, and much less attention has been paid to other pollutants from ship emissions, such as nitrogen oxides $\left(\mathrm{NO}_{x}\right)$ and volatile organic compounds (VOCs), although they are also important precursors to ozone and secondary aerosols (Chameides et al., 1992; Odum et al., 1997; Atkinson, 2000; O'Dowd et al., 2002). Cooper et al. (1996) found that many reactive VOCs, such as ethylene, propylene and isobutylene, were found in emissions from passenger ferries in the Skagerak-Kattegatt-Öresund region; Agrawal et al. (2008) reported emissions of VOCs including carbonyls, 1,3-butadiene, aromatics and $n$-alkanes from the main engine, auxiliary engine and boiler of a Suezmax class vessel; Agrawal et al. (2010) and Murphy et al. (2009) further calculated their emission factors based on shipboard platform measurements and aircraft-based measurements for the main engine of a Panamax class container ship. Recently, Huang et al. (2018a) tested a Handysize class bulk carrier under atberth, maneuvering and cruising conditions, and found that single-ring aromatics accounted for $50 \%-74 \%$ of the VOCs with toluene as the most abundant species. Xiao et al. (2018) tested 20 ships at berth in the Port of Jingtang in northern China and found that alkanes and aromatics were dominant in the VOC emissions. Previous studies have already demonstrated that ship emissions impact ambient ozone formation in coastal cities (R. N. Wang et al., 2019). In addition, ship emissions could contribute substantially to $\mathrm{NO}_{x}$ in the oceans and coastal areas (Song et al., 2010; Tagaris et al., 2017). Therefore, even in terms of lowering ambient ozone levels, there is a growing concern about ship emissions as ozone precursors, including $\mathrm{NO}_{x}$ and VOCs.

China has many of the world's busiest ports, sharing approximately $10 \%$ of global ship emissions (Fu et al., 2017). To reduce ship emissions, China has also designated three ECAs, namely the Pearl River Delta (PRD), the Yangtze River Delta and the Bohai Rim, where ships have been required to gradually switch to fuels with an FSC limit of $0.5 \%$ from 1 January 2017 to 31 December 2019. As estimated by Liu et al. (2018), this fuel switch policy could lower atmospheric concentrations of $\mathrm{SO}_{2}$ and $\mathrm{PM}_{2.5}$ by $9.5 \%$ and $2.7 \%$, respectively, in the coastal region of the PRD in southern China. A recent field observation campaign in the Port of Jingtang also demonstrated that due to the implementation of the fuel switch policy (IFSP), ambient levels of $\mathrm{SO}_{2}$ dropped from 165.5 to $67.4 \mathrm{ppb}$, while particulate vanadium (V), a marker of ship PM emissions (Agrawal et al., 2009; Pey et al., 2013; Perez et al., 2016; Tao et al., 2017), decreased drastically from 309.9 to $9.1 \mathrm{ng} \mathrm{m}^{-3}$ (Zhang et al., 2019). However, it is still unknown whether the fuel switch policy will result in changes in ship emissions of VOCs.

For ships at berth, their main engines are shut down, and auxiliary engines become the only emissions source. Because a ship is usually at berth for a day or more, and the place where its auxiliary engine discharges pollutants is usually closer to densely populated areas, emissions from ships at berth could have a large impact on coastal areas (Cooper, 2003). In the present study, we conducted shipboard platform measurements of air pollutants emitted from coastal vessels at berth in the Port of Guangzhou in the PRD region in southern China in 2017 and 2018 after IFSP, and we compared the results with those from a similar campaign previously conducted by the authors in 2015 and 2016 before IFSP. Apart from the emissions of pollutants such as $\mathrm{PM}_{2.5}$ and $\mathrm{SO}_{2}$, in this study we focus on emissions of VOCs, and we aim to investigate changes in composition profiles and emission factors of VOCs from ships at berth and to assess the potential influence on the formation of ozone $\left(\mathrm{O}_{3}\right)$ and secondary 
organic aerosol (SOA) due to the fuel switch policy. In addition, river vessels, which commonly use diesel oil as fuel and did not need to implement the fuel switch policy, were also tested in 2017 for a comparison with the coastal vessels that had implemented the policy.

\section{Experimental section}

\subsection{Study area}

The Port of Guangzhou is located in the estuary of the Pearl River and the center of the PRD region, adjacent to Hong Kong and Macao (Fig. 1). In 2017, cargo throughput of the Port of Guangzhou was 590 million tonnes, ranking fifth in China and sixth in the world, and the container throughput in the Port of Guangzhou was 20.37 million TEU (twentyfoot equivalent unit), ranking fifth in China and seventh in the world (China Port Press, 2018). In 2013, the Port of Guangzhou was estimated to account for nearly $40 \%$ of ship emissions of $\mathrm{SO}_{2}, \mathrm{NO}_{x}, \mathrm{CO}, \mathrm{PM}_{10}, \mathrm{PM}_{2.5}$ and VOCs from the nine port groups in the PRD bay area (C. Li et al., 2016).

\subsection{Test ships and fuel types}

As required, the FSC for ships at berth should have been less than $0.5 \%$ since 1 January 2017. In the PRD, measures are even more stringent in which ships at berth should use diesel oil that conforms to Chinese national standard GB252-2015 (Standards Press of China, 2015). Table 1 presents the basic information for the 11 tested ships (more information during sampling is presented in Table S1 in the Supplement), among which ships $C$ and $D$ were tested both before and after IFSP. According to the classification of ships by C. Li et al. (2016), ships $\mathrm{H}, \mathrm{I}, \mathrm{J}$ and $\mathrm{K}$ were river vessels, which were not regulated because they already used diesel oil as fuel before IFSP, and the others were coastal vessels. No ocean-going ships were tested in this study.

\subsection{Ship exhaust sampling and laboratory analysis}

The ship exhaust sampling system is composed of a flue gas dilution system, flue gas analyzer, particulate matter sampler and air sampler (Fig. 2). The ship exhaust first entered the Dekati ${ }^{\circledR}$ ejector diluter (DI-1000, Dekati Ltd., Finland) from the sampling nozzle, and it was then split into four parts after being diluted with clean air: one part was for air sampling with $2 \mathrm{~L}$ canisters and $4 \mathrm{~L}$ Teflon bags for 3-5 min after passing through a filter, two other parts were for collecting $\mathrm{PM}_{2.5}$ samples with $47 \mathrm{~mm}$ Teflon filters (Whatman, Mainstone, UK) and $47 \mathrm{~mm}$ quartz fiber filters (Whatman, Mainstone, UK) at a flow of $16.7 \mathrm{~L} \mathrm{~min}^{-1}$ for $20-30 \mathrm{~min}$, after the diluted exhaust was mixed well in a mixing chamber, and then passing through a $\mathrm{PM}_{2.5}$ separator; the last part was the vent. Before dilution, the concentrations of $\mathrm{CO}_{2}, \mathrm{CO}, \mathrm{SO}_{2}$ and $\mathrm{NO}_{x}$ in the ship exhaust were directly measured by a flue gas analyzer (F-550, Wöhler, Germany), while air samples were also collected simultaneously by $2 \mathrm{~L}$ canisters and $4 \mathrm{~L}$ Teflon bags. The dilution ratios of the flue gas dilution system were then more accurately calculated by comparing the $\mathrm{CO}_{2}$ concentrations in the samples before and after the dilution. In addition, $500 \mathrm{~mL}$ of the fuel oil used by each ship was collected in brown glass bottles to determine its carbon and sulfur contents and to analyze the $\mathrm{C}_{11}-\mathrm{C}_{36}$ hydrocarbon species.

VOCs in the air samples collected in the canisters and Teflon bags were analyzed by using a preconcentrator (model 7100, Entech Instruments Inc., USA) coupled to an Agilent $5973 \mathrm{~N}$ gas chromatograph with a mass selective detector and a flame ionization detector (GC-MSD/FID, Agilent Technologies, USA). The calibration standards were prepared by dynamically diluting the $100 \mathrm{ppbv}$ Photochemical Assessment Monitoring Stations (PAMS) standard mixture and TO-14 standard mixture (39 compounds) from Spectra Gases Inc., NJ, USA, to 0.5, 1, 5, 15 and 30 ppbv. More details about the analysis are described elsewhere (Zhang et al., 2013, 2015; Yang et al., 2018). Besides measurements by the flue gas analyzer, the $\mathrm{CO}_{2} / \mathrm{CO}$ concentrations were also analyzed by gas chromatography (Agilent 6980GC, USA) with a flame ionization detector and a packed column $(5 \AA \AA$ molecular sieve, $60 / 80$ mesh, $3 \mathrm{~m} \times 1 / 8$ in.; Liu et al., 2015). The particulate samples collected by quartz filters were analyzed by a DRI model 2015 multi-wavelength thermal organic carbon (OC) and elemental carbon (EC) analyzer (Li et al., 2018). The carbon contents of the ship fuels were analyzed by an elemental analyzer (Vario EL III, Elementar, Germany), and the sulfur contents were analyzed by the conversion to sulfate with an oxygen bomb combustion (IKA AOD1, IKA, Germany) followed by the determination of sulfate with ion chromatography (883 Basic IC plus, Metrohm, Switzerland) (G. H. Li et al., 2016). The $\mathrm{C}_{11}-\mathrm{C}_{36}$ hydrocarbons in the fuels were analyzed with an Agilent 7890/5975C gas chromatograph with a mass spectrometer detector (GC/MSD) equipped with a HP-5MS capillary column (30 $\mathrm{m}$ in length, $0.25 \mathrm{~mm}$ i.d., $0.25 \mu \mathrm{m}$ film thickness) (Yu et al., 2018) after dissolving $50 \mu \mathrm{L}$ fuel oil in $1 \mathrm{~mL} n$-hexane and removing the insoluble material by filtration.

\subsection{Calculations of emission factors}

The emission factors (EFs) were calculated by a carbon balance approach, which assumed that the carbon in fuel was transformed into the carbon in $\mathrm{CO}_{2}, \mathrm{CO}, \mathrm{PM}$ and VOCs, and the $\mathrm{EF}$ of $\mathrm{CO}_{2}$ was calculated as follows (Liu et al., 2014):

$$
\mathrm{EF}_{\mathrm{CO}_{2}}=\frac{\mathrm{C}_{\mathrm{F}} \cdot \Delta\left[\mathrm{CO}_{2}\right]}{\Delta \mathrm{C}_{\mathrm{CO}_{2}}+\Delta \mathrm{C}_{\mathrm{CO}}+\Delta \mathrm{C}_{\mathrm{PM}}+\Delta \mathrm{C}_{\mathrm{VOCs}}},
$$

where $\mathrm{EF}_{\mathrm{CO}_{2}}$ is the emission factor of $\mathrm{CO}_{2}\left(\mathrm{~g} \mathrm{~kg}^{-1}\right)$; $\mathrm{C}_{\mathrm{F}}$ is the carbon content per kilogram of fuel $\left(\mathrm{g} \mathrm{kg}^{-1}\right) ; \Delta\left[\mathrm{CO}_{2}\right]$ is the incremental concentrations of $\mathrm{CO}_{2} ; \Delta \mathrm{C}_{\mathrm{CO}_{2}}, \Delta \mathrm{C}_{\mathrm{CO}}$, $\Delta \mathrm{C}_{\mathrm{PM}}$ and $\Delta \mathrm{C}_{\mathrm{VOCs}}$ represent the carbon mass concentra- 
Table 1. The basic information of test vessels.

\begin{tabular}{|c|c|c|c|c|c|c|c|c|c|}
\hline \multirow[t]{2}{*}{ Ship } & \multirow[t]{2}{*}{ Test date } & \multirow[t]{2}{*}{ Ship type } & \multirow[t]{2}{*}{ Gross tonnage $(\mathrm{t})$} & \multirow[t]{2}{*}{ Vessel age (year) } & \multicolumn{2}{|c|}{ Auxiliary engine } & \multicolumn{3}{|c|}{ Fuel types } \\
\hline & & & & & Power $(\mathrm{kW})$ & Number & Type & $\mathrm{C} \%$ & $\mathrm{~S} \%$ \\
\hline \multicolumn{10}{|c|}{ Coastal vessels (before IFSP) } \\
\hline \multirow[t]{2}{*}{ A } & 2015.12 .17 & container vessel & 47917 & 3 & 1760 & 2 & residual oil & 84.9 & 1.60 \\
\hline & & & & & 1320 & 1 & & & \\
\hline $\mathrm{B}$ & 2016.08 .19 & container vessel & 41482 & 8 & 2045 & 3 & residual oil & 82.9 & 2.90 \\
\hline \multirow[t]{2}{*}{ C-1 } & 2016.08 .19 & container vessel & 49437 & 4 & 1760 & 2 & residual oil & 82.7 & 2.10 \\
\hline & & & & & 1320 & 1 & & & \\
\hline D-1 & 2016.11 .15 & bulk carrier & 38384 & 3 & 660 & 3 & residual oil & 84.4 & 2.20 \\
\hline \multicolumn{10}{|c|}{ Coastal vessels (after IFSP) } \\
\hline $\mathrm{E}$ & 2017.03 .29 & bulk carrier & 8376 & 8 & 200 & 2 & diesel oil & 86.6 & 0.68 \\
\hline $\mathrm{F}$ & 2017.12 .22 & bulk carrier & 10716 & 10 & 200 & 3 & diesel oil & 86.6 & 0.13 \\
\hline \multirow[t]{2}{*}{ C-2 } & 2018.04 .21 & container vessel & 49437 & 6 & 1760 & 2 & diesel oil & 85.8 & $<0.01$ \\
\hline & & & & & 1320 & 1 & & & \\
\hline G & 2018.05 .03 & container vessel & 25719 & 19 & 500 & 3 & $\begin{array}{l}\text { heavy oil } \\
\text { (low sulfur) }\end{array}$ & 86.5 & 1.14 \\
\hline D-2 & 2018.05 .06 & bulk carrier & 38384 & 4 & 660 & 3 & $\begin{array}{l}\text { heavy oil } \\
\text { (low sulfur) }\end{array}$ & 87.5 & 0.47 \\
\hline \multicolumn{10}{|c|}{ River vessels } \\
\hline \multirow[t]{2}{*}{$\mathrm{H}$} & 2017.03 .29 & dry cargo carrier & 2445 & 9 & 144 & 2 & diesel oil & 86.0 & 0.06 \\
\hline & & & & & 76 & 1 & & & \\
\hline I & 2017.09 .27 & container vessel & 1862 & 7 & 73.5 & 2 & diesel oil & 86.0 & 0.03 \\
\hline $\mathrm{J}$ & 2017.09 .27 & container vessel & 1357 & 15 & 58 & 2 & diesel oil & 86.1 & 0.03 \\
\hline $\mathrm{K}$ & 2017.09 .27 & container vessel & 1420 & 10 & 58.5 & 2 & diesel oil & 85.9 & 0.02 \\
\hline
\end{tabular}

tions of $\mathrm{CO}_{2}, \mathrm{CO}, \mathrm{PM}$ and VOCs, respectively, after subtracting their background concentrations.

The EF of a pollutant $i$ was calculated by

$\mathrm{EF}_{i}=\frac{\Delta[i]}{\Delta\left[\mathrm{CO}_{2}\right]} \times \mathrm{EF}_{\mathrm{CO}_{2}}$,

where $\Delta[i]$ is the incremental concentration of pollutant $i$.

According to the standard method ISO 8178-1, the sulfur in fuel is assumed to be fully transformed into $\mathrm{SO}_{2}$, so we used Eq. (3) to calculate the EF of $\mathrm{SO}_{2}$ (Y. L. Zhang et al., 2018):

$\mathrm{EF}_{\mathrm{SO}_{2}}=S \% \times \frac{64}{32} \times 10^{3}$

where $\mathrm{EF}_{\mathrm{SO}_{2}}$ is the $\mathrm{EF}$ of $\mathrm{SO}_{2}\left(\mathrm{~g} \mathrm{~kg}^{-1}\right)$, and $\mathrm{S} \%$ represents FSC.

\section{Results and discussion}

\subsection{Changes in EFs for ships at berth}

The FSC for the tested coastal vessels decreased from $2.2 \pm$ $0.5 \%$ on average before IFSP to $0.4 \pm 0.5 \%$ after IFSP, although there were some ships, such as ship $\mathrm{G}$, which violated the regulation with an FSC still above the limit of $0.5 \%$ (Table 1). In fact, the ship fuel was transferred from residual fuel oil to diesel oil or heavy oil (Fig. S1 in the Supplement), and the compositions of the fuels used by the coastal vessels tended to have more low-carbon-number hydrocarbons, as demonstrated by their total ion chromatograms, than those of coastal vessels before IFSP (Fig. S2).

As shown in Table 2, the EFs for $\mathrm{SO}_{2}$, which were independent of the combustion system (Corbett et al., 1999), decreased by $78.0 \%$ from $44.0 \pm 10.5$ to $9.66 \pm 7.97 \mathrm{~g} \mathrm{~kg}^{-1}$ on average. Fuel-based EFs for $\mathrm{CO}_{2}, \mathrm{CO}, \mathrm{NO}_{x}\left(\mathrm{NO}+\mathrm{NO}_{2}\right)$, VOCs, $\mathrm{PM}_{2.5}$, OC and EC, however, were more complex, because they are not only related to the properties of the fuels but also heavily influenced by the performance of the 


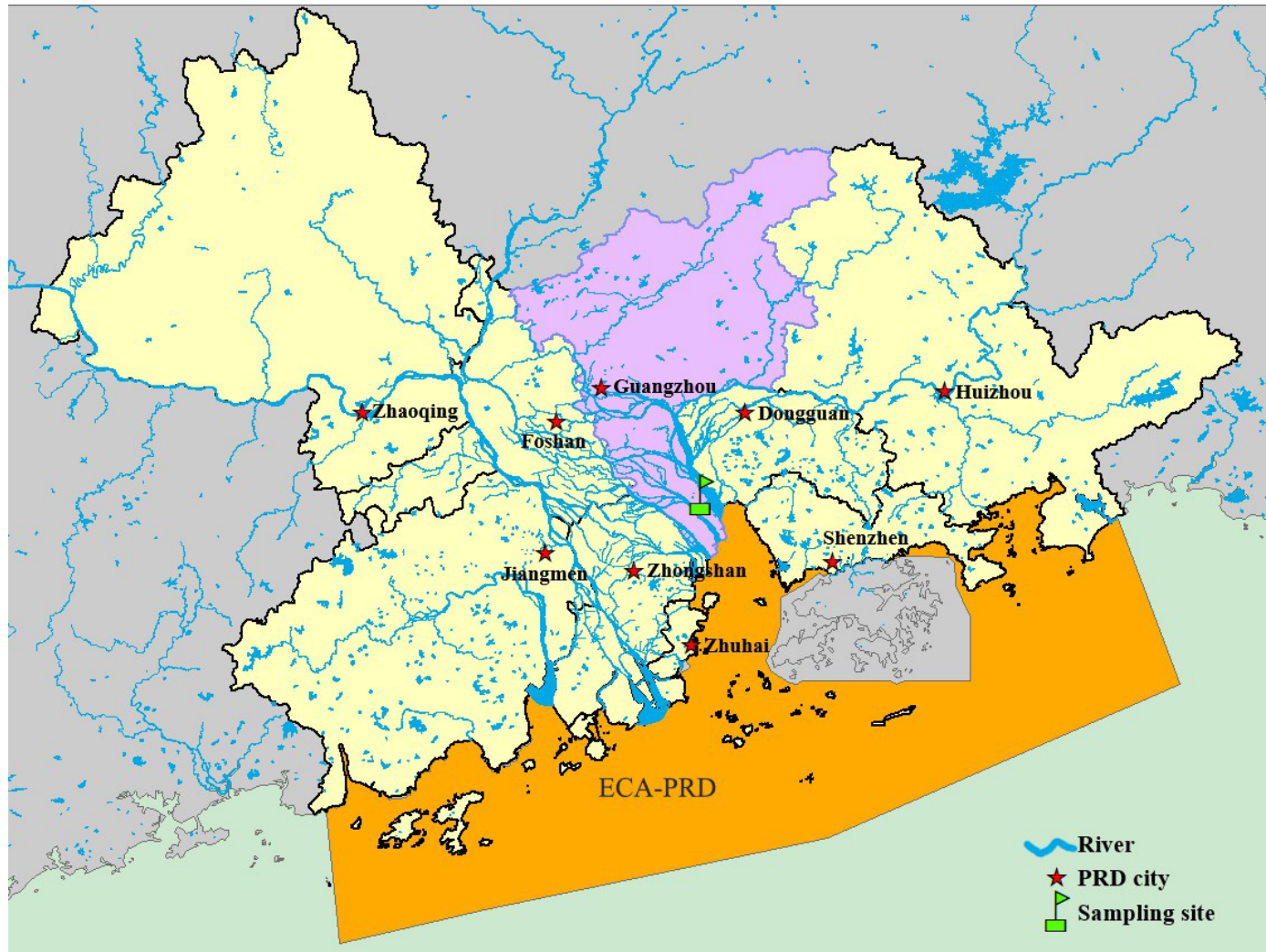

Figure 1. The realm of ECA-PRD and the sampling site.

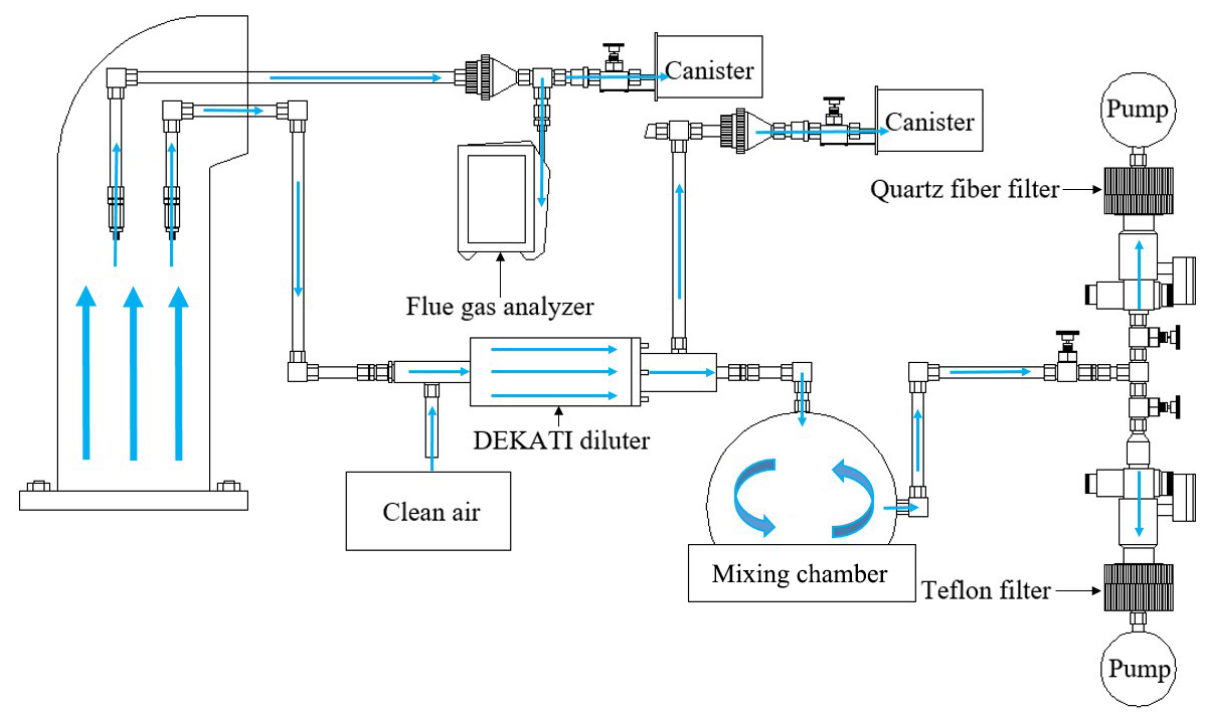

Figure 2. Schematic diagram of sampling setup.

combustion system. The comparison before and after IFSP was also challenged by the fact that the tested coastal vessels during the two campaigns were not the same and that we tested a limited number of ships. Nevertheless, ships C and $\mathrm{D}$ were tested both before and after IFSP and we compared them. The EFs of $\mathrm{CO}_{2}$ for ships $\mathrm{C}$ and $\mathrm{D}$ slightly in- creased from 3025 and 3069 to 3131 and $3196 \mathrm{~g} \mathrm{~kg}^{-1}$, respectively, after IFSP; the EF of CO for ship C increased from 3.80 to $6.16 \mathrm{~g} \mathrm{~kg}^{-1}$, but that for ship D decreased from 14.6 to $6.41 \mathrm{~g} \mathrm{~kg}^{-1}$; the $\mathrm{EF}$ of $\mathrm{NO}_{x}$ for ship C slightly decreased from 19.9 to $19.0 \mathrm{~g} \mathrm{~kg}^{-1}$, while that for ship D decreased from 51.5 to $31.1 \mathrm{~g} \mathrm{~kg}^{-1}$. 
Table 2. The emission factors for test vessels $\left(\mathrm{g} \mathrm{kg}^{-1}\right)$.

\begin{tabular}{|c|c|c|c|c|c|c|c|c|}
\hline Ship & $\mathrm{CO}_{2}$ & $\mathrm{CO}$ & $\mathrm{SO}_{2}$ & $\mathrm{NO}_{x}$ & VOCs & $\mathrm{OC}$ & $\mathrm{EC}$ & $\mathrm{PM}_{2.5}$ \\
\hline \multicolumn{9}{|c|}{ Coastal vessels (before IFSP) } \\
\hline A & 3097 & 8.03 & 32.0 & 61.7 & 0.11 & 0.59 & 0.15 & 2.30 \\
\hline B & 3029 & 5.33 & 58.0 & 29.1 & 0.20 & 0.29 & 0.05 & 1.46 \\
\hline $\mathrm{C}-1$ & 3025 & 3.80 & 42.0 & 19.9 & 0.11 & 0.22 & 0.07 & 1.02 \\
\hline D-1 & 3069 & 14.6 & 44.0 & 51.5 & 0.06 & 0.16 & 0.61 & 2.44 \\
\hline \multicolumn{9}{|c|}{ Coastal vessels (after IFSP) } \\
\hline $\mathrm{E}$ & 3120 & 24.2 & 13.5 & 56.6 & 1.68 & 1.41 & 2.08 & 8.46 \\
\hline $\mathrm{F}$ & 3156 & 5.50 & 2.52 & 13.0 & 1.11 & 0.55 & 1.41 & 2.17 \\
\hline $\mathrm{C}-2$ & 3130 & 6.16 & 0.06 & 19.0 & 0.71 & 0.16 & 0.29 & 0.56 \\
\hline G & 3079 & 41.0 & 22.8 & 19.2 & 5.25 & 2.05 & 1.49 & 5.90 \\
\hline D-2 & 3196 & 6.41 & 9.40 & 31.1 & 0.29 & 0.07 & 0.22 & 0.87 \\
\hline \multicolumn{9}{|c|}{ River vessels } \\
\hline $\mathrm{H}$ & 3087 & 26.2 & 1.20 & 25.0 & 0.81 & 0.74 & 5.21 & 12.5 \\
\hline I & 3055 & 59.6 & 0.52 & 13.3 & 1.40 & - & - & - \\
\hline $\mathrm{J}$ & 2865 & 171 & 0.68 & 9.77 & 6.93 & - & - & - \\
\hline K & 3050 & 55.0 & 0.36 & 64.4 & 4.29 & - & - & - \\
\hline
\end{tabular}

Similar to the EFs of $\mathrm{SO}_{2}$, the EFs of $\mathrm{PM}_{2.5}$ also decreased significantly after IFSP. For example, the EFs of $\mathrm{PM}_{2.5}$ for ship C decreased by $45.1 \%$ from 1.02 to $0.56 \mathrm{~g} \mathrm{~kg}^{-1}$ and that for ship D decreased by $64.3 \%$ from 2.44 to $0.87 \mathrm{~g} \mathrm{~kg}^{-1}$; similar to that of $\mathrm{PM}_{2.5}$, the EF of OC for ships $\mathrm{C}$ and D decreased by $28.7 \%$ and $60.5 \%$, but no significant change occurred in the EF of EC. Therefore, after IFSP, the changes in the $\mathrm{EFs}$ of $\mathrm{CO}_{2}, \mathrm{CO}, \mathrm{NO}_{x}$ and $\mathrm{EC}$ were not significant for the coastal vessels, but the EFs of $\mathrm{SO}_{2}, \mathrm{PM}_{2.5}$ and $\mathrm{OC}$ decreased.

Compared to $\mathrm{SO}_{2}$ or other pollutants, the VOCs from coastal vessels showed more dramatic changes in their EFs. As shown in Table 2, the EFs of the VOCs ranged from 60.7 to $197 \mathrm{mg} \mathrm{kg}^{-1}$ with an average of $118 \pm 56.1 \mathrm{mg} \mathrm{kg}^{-1}$ before IFSP, and they ranged from 292 to $5251 \mathrm{mg} \mathrm{kg}^{-1}$ with an average of $1807 \pm 1746 \mathrm{mg} \mathrm{kg}^{-1}$ after IFSP. For ships C and D that were tested both before and after IFSP, the EF of the VOCs for ship C increased approximately 6 times from 106 to $706 \mathrm{mg} \mathrm{kg}^{-1}$, and the EF for ship D also increased approximately 4 times from 60.7 to $292 \mathrm{mg} \mathrm{kg}^{-1}$. This substantial change in our study was consistent with that based on shipboard platform measurements by Cooper (2003), who also found that the EFs of hydrocarbons from a passenger ferry at berth increased from $0.29-0.57$ to $1.71 \mathrm{~g} \mathrm{~kg}^{-1}$ after replacing the residual oil ( $\mathrm{FSC}=0.53 \%$ ) with marine gas oil $(\mathrm{FSC}=0.09 \%)($ Table 3$)$.

There are only a few previous studies available on air pollutants from coastal vessels at berth (Table 3). The ranges for the EFs of $\mathrm{CO}_{2}$, PM, VOCs and $\mathrm{SO}_{2}$ in our study were similar to those determined by Cooper (2003), but our EFs of CO were much higher and our EFs of $\mathrm{NO}_{x}$ were much lower.
River vessels sail in inland rivers and many studies have investigated the emissions from river vessels under cruising conditions (Fu et al., 2013; Peng et al., 2016; Zhang et al., 2016), but no studies are available about their emissions at berth. In this study, river vessels used diesel as fuel, and they were not affected by the fuel switch policy. As shown in Table 3, for the tested river vessels (ships $\mathrm{H}, \mathrm{I}$, $\mathrm{J}$ and $\mathrm{K})$, the EFs of $\mathrm{CO}_{2}\left(3014 \pm 99.0 \mathrm{~g} \mathrm{~kg}^{-1}\right)$ and $\mathrm{NO}_{x}$ $\left(28.1 \pm 24.5 \mathrm{~g} \mathrm{~kg}^{-1}\right)$ were close to those for coastal vessels; the EF of CO $\left(77.9 \pm 62.5 \mathrm{~g} \mathrm{~kg}^{-1}\right)$, however, was nearly 4 times higher than that of coastal vessels after IFSP, and it was larger than that reported for engineering vessels and research vessels under cruising conditions with a maximum of $30.2 \mathrm{~g} \mathrm{~kg}^{-1}$ (Zhang et al., 2016); their EF of $\mathrm{SO}_{2}$ was as low as $0.69 \pm 0.36 \mathrm{~g} \mathrm{~kg}^{-1}$, while the EF of the VOCs was as high as $3.36 \pm 2.77 \mathrm{~g} \mathrm{~kg}^{-1}, 85.6 \%$ larger than that reported for coastal vessels after IFSP but within the range for research vessels $\left(1.24-4.18 \mathrm{~g} \mathrm{~kg}^{-1}\right)$ as reported by Zhang et al. (2016).

\subsection{EFs of grouped and individual VOCs}

The data on the EFs of grouped and individual VOCs are sparse (Cooper et al., 1996; Murphy et al., 2009; Agrawal et al., 2008, 2010), especially for ship emissions at berth. In this study, 68 species of VOCs, including 29 alkanes, 21 alkenes, 1 alkyne and 17 aromatics, were determined. As shown in Fig. 3 and Table 4, for coastal vessels before IFSP, alkanes dominated the emissions among the VOCs at $49.4 \pm 24.1 \%$ and an EF of $66.0 \pm 48.3 \mathrm{mg} \mathrm{kg}^{-1}$, while aromatics and alkenes accounted for $27.9 \pm 12.3 \%$ and $21.9 \pm 11.9 \%$ of the VOCs with EFs of $29.2 \pm 8.6$ and $21.9 \pm 4.5 \mathrm{mg} \mathrm{kg}^{-1}$, 
Table 3. Fuel-based average EFs $\left(\mathrm{g} \mathrm{kg}^{-1}\right)$ from this study in comparison with those reported previously.

\begin{tabular}{|c|c|c|c|c|c|c|c|c|}
\hline Ship & FSC & Condition & $\mathrm{CO}_{2}$ & $\mathrm{CO}$ & PM & VOCs & $\mathrm{SO}_{2}$ & $\mathrm{NO}_{x}$ \\
\hline Coastal vessels (before IFSP) ${ }^{\mathrm{a}}$ & $>0.5 \%$ & At berth & 3055 & 7.93 & 1.81 & 0.12 & 44.0 & 40.6 \\
\hline Passenger ferry $\alpha^{\mathrm{b}}$ & $0.08 \%$ & At berth & $3080-3297$ & $2.69-4.58$ & $0.99-2.12$ & $0.57-0.99$ & $1.56-1.65$ & $70.3-90.6$ \\
\hline Passenger ferry $\beta-1^{\mathrm{b}}$ & $0.53 \%$ & At berth & $3121-3284$ & $4.34-6.99$ & 1.96 & $0.29-0.57$ & $10.2-11.0$ & $54.4-71.6$ \\
\hline Car/truck carrier ${ }^{\mathrm{b}}$ & $0.23 \%$ & At berth & $3237-3251$ & $4.31-4.59$ & $0.80-0.89$ & $0.89-1.08$ & 4.68 & $45.0-46.4$ \\
\hline Container/ro-ro ${ }^{\mathrm{b}}$ & $2.20 \%$ & At berth & $3199-3212$ & $3.55-4.17$ & $2.49-3.10$ & $0.79-0.88$ & $44.0-44.2$ & $59.4-70.4$ \\
\hline Chemical tanker ${ }^{\mathrm{b}}$ & $0.06 \%$ & At berth & 3159 & $3.22-3.41$ & $0.65-0.75$ & $1.36-1.40$ & 1.21 & $81.8-83.6$ \\
\hline Panamax class container ${ }^{\mathrm{c}}$ & $3.01 \%$ & Cruising & 2805 & 1.32 & 10.9 & - & 52.40 & 89.9 \\
\hline \multicolumn{9}{|l|}{ River vessels } \\
\hline Research vessel $\beta^{\mathrm{d}}$ & $0.13 \%$ & Cruising & 3151 & 9.20 & 0.16 & 4.18 & 2.60 & 31.6 \\
\hline
\end{tabular}

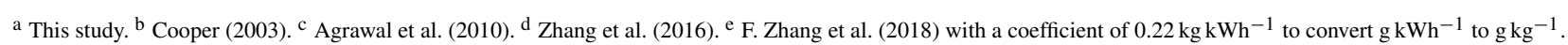

respectively. However, there were dramatic changes in the compositions of the VOCs after IFSP. Alkenes overtook alkanes to become the most abundant group at $43.1 \% \pm 12.8 \%$ and an $\mathrm{EF}$ of $924.6 \pm 1314.9 \mathrm{mg} \mathrm{kg}^{-1}$, followed by alkanes $\left(33.0 \pm 17.5 \%, 339.2 \pm 176.6 \mathrm{mg} \mathrm{kg}^{-1}\right)$ and aromatics $\left(16.1 \pm 4.1 \%, 247.3 \pm 236.4 \mathrm{mg} \mathrm{kg}^{-1}\right)$. In addition, the mass percentages of $<\mathrm{C}_{6}$ VOCs (VOCs with carbon numbers below 6) in the total VOCs in ship exhaust increased from $8.5 \%-27.3 \%$ to $44.4 \%-86.6 \%$ after IFSP (Fig. S3), which indicated more low-carbon-number VOCs were emitted from ships at berth.

For the EFs of the individual VOCs, the top 25 species remained unchanged after IFSP, but their rankings changed (Table S2). As shown in Fig. 4 and Table 4, n-undecane and $n$-dodecane were still among the dominant species, although their percentages decreased substantially. Their EFs did not change to the same degree and were $22.5 \pm 18.2$ and $21.5 \pm 17.1 \mathrm{mg} \mathrm{kg}^{-1}$ before IFSP and $22.5 \pm 24.6$ and $32.1 \pm$ $62.1 \mathrm{mg} \mathrm{kg}^{-1}$ after IFSP, respectively. In addition, the EF of isobutane increased from $0.06 \pm 0.07$ to $94.3 \pm 62.2 \mathrm{mg} \mathrm{kg}^{-1}$. A striking increase in EFs was also observed for alkenes. Ethylene overtook 1-hexene to become the most abundant alkene, with its EF increasing from 2.8 to $602 \mathrm{mg} \mathrm{kg}^{-1}$ on average. Propene, with an EF of $5.5 \pm 1.5 \mathrm{mg} \mathrm{kg}^{-1}$ before IFSP, had the second largest EF of $198 \pm 260 \mathrm{mg} \mathrm{kg}^{-1}$ after IFSP, an increase of over 30 times. The alkene 1-hexene, which ranked first among alkenes with an EF of $5.9 \pm 3.8 \mathrm{mg} \mathrm{kg}^{-1}$ before IFSP, also increased 1.9 times to $17.3 \pm 19.4 \mathrm{mg} \mathrm{kg}^{-1}$. The mass percentages of acetylene, the only alkyne detected, increased from $0.9 \pm 0.6 \%$ to $7.5 \pm 7.6 \%$, with its EF increasing from $0.9 \pm 0.6$ to $328.7 \pm 605.4 \mathrm{mg} \mathrm{kg}^{-1}$. Ben-

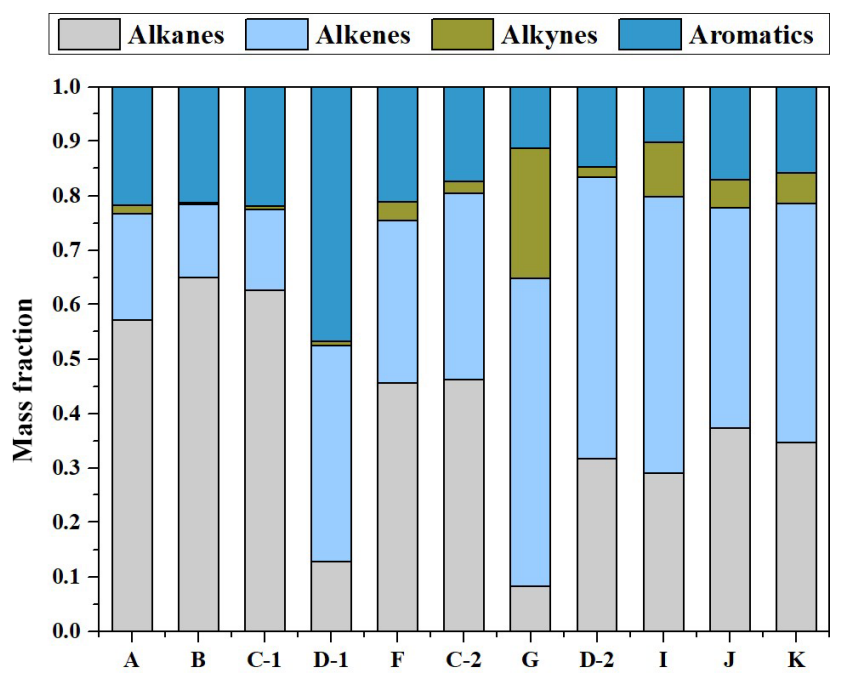

Figure 3. VOC grouping according to their functional group. A, B, C-1 and D-1 are coastal vessels tested before IFSP; F, G, C-2 and D-2 are coastal vessels tested after IFSP; and I, J and K are river vessels tested.

zene and toluene were the dominant aromatic species before and after IFSP. Their EFs increased from $11.9 \pm 4.6$ and $6.0 \pm 1.2 \mathrm{mg} \mathrm{kg}^{-1}$ to $116.5 \pm 200.8$ and $33.3 \pm 42.5 \mathrm{mg} \mathrm{kg}^{-1}$, respectively, after IFSP.

The composition of the VOCs from the river vessels was similar to that of the coastal vessels after IFSP. As shown in Fig. 3 and Table S2, alkenes were also dominant in the emissions of the VOCs at $45.1 \pm 5.9 \%$, while aromatics and 
Table 4. Emission factors ( $\mathrm{mg} \mathrm{kg}^{-1}$ ) of VOCs for test vessels.

\begin{tabular}{|c|c|c|c|c|c|c|c|c|c|c|c|}
\hline \multirow[t]{2}{*}{ Species } & \multicolumn{4}{|c|}{ Coastal vessels (before IFSP) } & \multicolumn{4}{|c|}{ Coastal vessels (after IFSP) } & \multicolumn{3}{|c|}{ River vessels } \\
\hline & A & B & $\mathrm{C}-1$ & D-1 & $\mathrm{F}$ & $\mathrm{C}-2$ & G & D-2 & I & $\mathrm{J}$ & $\mathrm{K}$ \\
\hline Ethane & 0.1 & 0.1 & 0.1 & 0.1 & 8.8 & 5.6 & 99.0 & 3.4 & 17.4 & 59.4 & 31.6 \\
\hline Propane & 0.1 & 0.1 & 0.1 & 0.1 & 14.6 & 3.6 & 24.5 & 2.7 & 2.4 & 9.0 & 7.5 \\
\hline n-Butane & 0.3 & 0.1 & 0.4 & 0.0 & 5.6 & 20.7 & 15.4 & 19.3 & 0.6 & 2.1 & 149.3 \\
\hline$n$-Hexane & 0.4 & 1.7 & 1.0 & 0.4 & 5.0 & 1.4 & 2.8 & 3.6 & 0.3 & 3.6 & 0.6 \\
\hline n-Octane & 0.8 & 1.0 & 0.7 & 0.3 & 9.6 & 4.5 & 1.2 & 0.7 & 4.9 & 57.7 & 26.3 \\
\hline$n$-Nonane & 4.6 & 4.5 & 4.1 & 0.3 & 43.0 & 37.3 & 1.4 & 0.9 & 20.5 & 199.6 & 144.5 \\
\hline$n$-Decane & 2.4 & 23.2 & 15.2 & 0.8 & 117.3 & 97.9 & 2.2 & 1.7 & 32.8 & 300.5 & 247.5 \\
\hline$n$-Undecane & 21.0 & 45.7 & 22.9 & 0.3 & 45.6 & 42.8 & 0.7 & 0.7 & 24.7 & 195.9 & 179.9 \\
\hline$n$-Dodecane & 26.8 & 42.5 & 15.5 & 1.3 & 127.2 & 1.0 & 0.2 & 0.1 & 0.7 & 6.8 & 57.6 \\
\hline Isobutane & 0.2 & 0.04 & 0.04 & $\mathrm{ND}^{\mathrm{e}}$ & 88.5 & 73.3 & 180.0 & 35.2 & 252.1 & 1336.5 & 459.1 \\
\hline Isopentane & 2.2 & 1.1 & 2.0 & 1.2 & 14.5 & 14.1 & 35.6 & 7.6 & 23.6 & 171.3 & 73.4 \\
\hline 3-Methylhexane & 0.8 & 1.0 & 1.5 & 0.3 & 3.1 & 1.4 & 15.6 & 1.0 & 7.0 & 36.8 & 35.0 \\
\hline TM224PE & ND & 4.1 & 1.3 & 2.2 & 2.8 & 4.0 & 18.0 & 1.4 & 9.0 & 73.5 & 32.8 \\
\hline Other alkanes & 1.8 & 3.0 & 1.8 & 0.6 & 21.2 & 18.4 & 34.6 & 14.4 & 11.1 & 129.0 & 43.2 \\
\hline Sum of alkanes & 61.5 & 128.3 & 66.5 & 7.8 & 506.8 & 326.2 & 431.1 & 92.7 & 407.1 & 2581.9 & 1488.4 \\
\hline Ethylene & 2.9 & 3.2 & 2.2 & 3.1 & 170.5 & 96.7 & 2062.7 & 79.3 & 401.8 & 1155.1 & 1125.2 \\
\hline Propene & 7.1 & 6.3 & 3.7 & 4.9 & 82.8 & 71.1 & 595.2 & 42.8 & 201.1 & 969.5 & 378.3 \\
\hline 1-Butene & 2.1 & 0.6 & 2.6 & 1.7 & 23.9 & 21.1 & 102.7 & 10.1 & 32.0 & 149.0 & 105.6 \\
\hline Trans-2-butene & 0.6 & 0.4 & 0.5 & 0.5 & 3.9 & 5.5 & 17.6 & 1.7 & 5.7 & 34.0 & 21.0 \\
\hline 1-Pentene & 4.1 & 2.0 & 1.2 & 2.9 & 17.3 & 14.7 & 57.9 & 5.2 & 24.7 & 143.1 & 80.4 \\
\hline 1-Hexene & 2.5 & 10.3 & 2.8 & 8.1 & 7.9 & 11.1 & 46.6 & 3.5 & 18.0 & 127.1 & 68.9 \\
\hline M4PE1ENE ${ }^{b}$ & 0.7 & 1.1 & 0.3 & 0.7 & 1.4 & 1.5 & 10.4 & 0.6 & 3.0 & 26.4 & 12.6 \\
\hline Other alkenes & 1.1 & 2.7 & 2.4 & 2.2 & 23.1 & 19.9 & 82.5 & 7.2 & 26.1 & 206.0 & 96.8 \\
\hline Sum of alkenes & 21.1 & 26.5 & 15.8 & 24.0 & 330.8 & 241.6 & 2975.6 & 150.4 & 712.5 & 2810.3 & 1888.8 \\
\hline Acetylene & 1.8 & 0.7 & 0.6 & 0.5 & 38.5 & 15.4 & 1255.1 & 5.6 & 139.1 & 355.5 & 241.8 \\
\hline Benzene & 9.6 & 11.6 & 7.9 & 18.6 & 18.3 & 13.0 & 423.7 & 10.9 & 46.6 & 191.7 & 129.5 \\
\hline Toluene & 5.4 & 7.6 & 4.8 & 6.3 & 15.7 & 7.8 & 98.2 & 11.7 & 22.1 & 131.3 & 75.5 \\
\hline Ethylbenzene & 1.1 & 2.5 & 1.8 & 0.7 & 7.4 & 5.3 & 13.1 & 3.0 & 6.3 & 61.5 & 28.2 \\
\hline$m / p$-Xylene & 1.8 & 3.5 & 1.7 & 1.3 & 24.1 & 19.4 & 20.4 & 7.0 & 11.5 & 129.1 & 57.4 \\
\hline$o$-Xylene & 0.6 & 1.5 & 0.7 & 0.5 & 14.1 & 10.1 & 9.3 & 2.9 & 6.3 & 69.1 & 31.6 \\
\hline$m$-Ethyltoluene & 0.7 & 1.5 & 0.5 & 0.2 & 24.8 & 11.4 & 2.0 & 1.4 & 8.4 & 100.0 & 75.9 \\
\hline$o$-Ethyltoluene & 0.3 & 1.2 & 0.6 & 0.1 & 16.8 & 6.1 & 1.7 & 0.9 & 5.0 & 54.2 & 28.9 \\
\hline $\mathrm{TM}_{123 \mathrm{~B}^{\mathrm{c}}}$ & 1.1 & 2.4 & 1.1 & 0.2 & 19.7 & 9.5 & 2.2 & 0.8 & 5.5 & 71.1 & 43.9 \\
\hline TM124B ${ }^{d}$ & 1.0 & 5.3 & 2.1 & 0.2 & 44.1 & 18.3 & 3.3 & 1.6 & 15.2 & 167.8 & 99.7 \\
\hline Other aromatics & 1.7 & 4.6 & 2.2 & 0.3 & 49.1 & 21.6 & 15.5 & 2.8 & 15.5 & 206.2 & 105.2 \\
\hline Sum of aromatics & 23.3 & 41.8 & 23.2 & 28.4 & 234.0 & 122.6 & 589.5 & 43.0 & 142.5 & 1182.0 & 675.7 \\
\hline
\end{tabular}

a 2,2,4-Trimethylpentane. ${ }^{\mathrm{b}}$ 4-Methyl-1-pentene. ${ }^{\mathrm{c}}$ 1,2,3-Trimethylbenzene. ${ }^{\mathrm{d}}$ 1,2,4-Trimethylbenzene. ${ }^{\mathrm{e}}$ Not detected.

alkenes accounted for $33.7 \pm 4.8 \%$ and $14.3 \pm 4.1 \%$, respectively. For the individual VOCs, the most abundant species were ethylene, isobutene, propene, acetylene, $n$-decane and benzene. However, the EFs of the VOCs for the river vessels were 1.9 times those of the coastal vessels after IFSP (Table 2), suggesting that VOC emissions from the river vessels might have played an important role as their emissions are closer to populated areas and thus should be regulated.

Recently, both Xiao et al. (2018) and Huang et al. (2018a) carried out VOC emissions tests on ships at berth in China's ECAs. Xiao et al. (2018) reported that aromatics and alkanes dominated the VOC emissions from the ships at berth. Furthermore, the most abundant alkane species were $n$-heptane, methylcyclohexane, $n$-octane, $n$-nonane, $n$-decane and $n$ undecane, and benzene and toluene accounted for $9 \%$ of the VOC emissions; Huang et al. (2018a) also investigated the VOC emissions from ships at berth, but aromatics accounted for up to $70.9 \%$ of those emissions, while alkenes only accounted for $6.7 \%$. The variation in ship fuels might be one of the key reasons for the large differences in the compositions of the VOC emissions among the available studies. The fuel switch policy restricted only the FSC below $0.5 \%$, so 


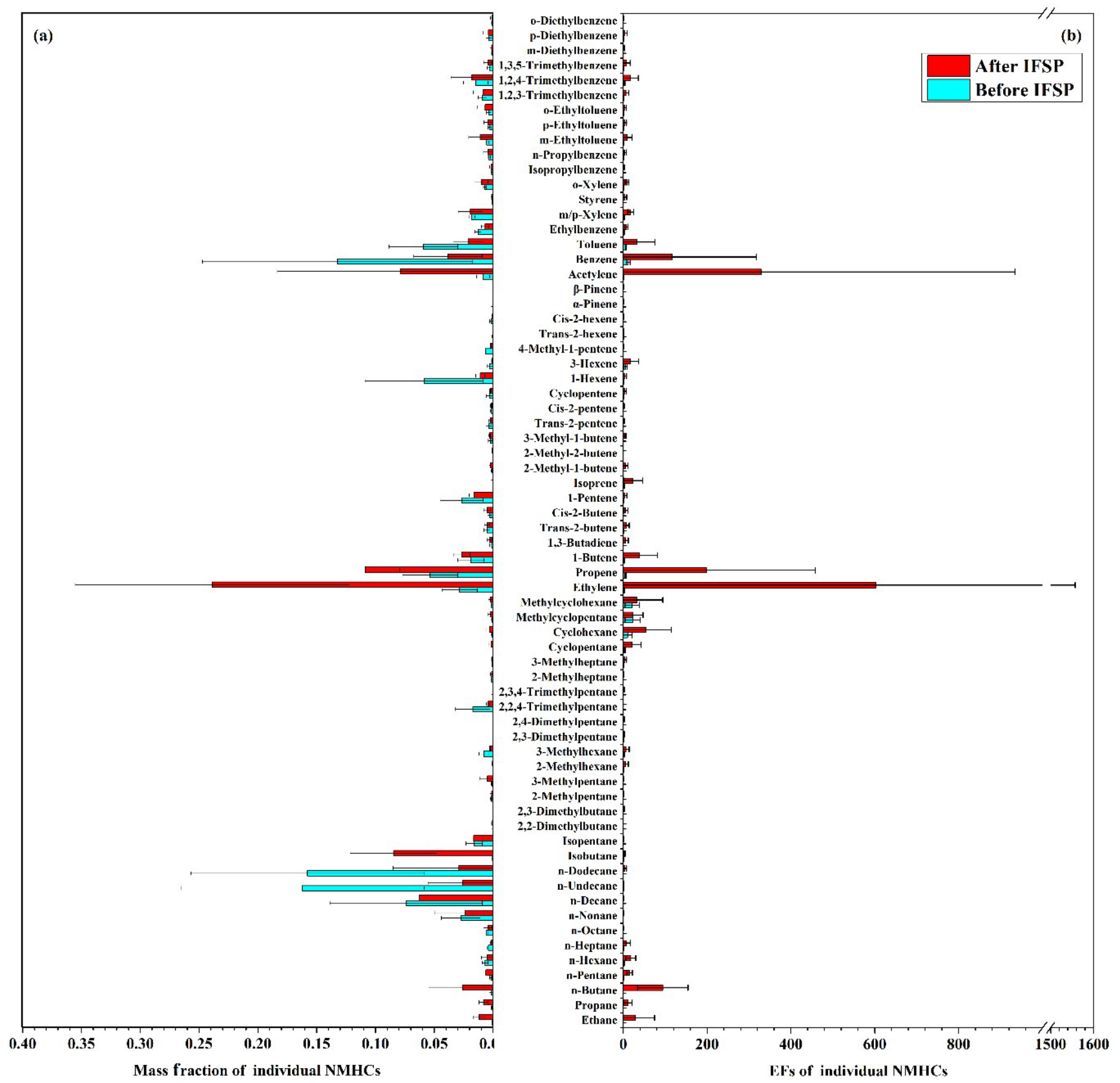

Figure 4. Comparison of VOCs emission factors before and after IFSP for coastal vessels.

many types of fuels could be used in ships, as seen from the four types of diesel fuels used by the tested ships (Fig. S1). Nonetheless, engine designs, performance and loads during the sampling might have also led to the differences (Cooper et al., 1996).

\subsection{Ozone and SOA formation potential}

\subsubsection{OFP of the VOCs from ship exhaust}

Ozone formation potential (OFP) is the approach that uses maximum incremental reactivity (MIR) to represent the maximum contribution of VOCs to near-surface ozone formation under optimal conditions (Carter, 2009). With ship emissions data in this study, the normalized ozone reactivity $\left(R_{\mathrm{O}_{3}}\right.$, 

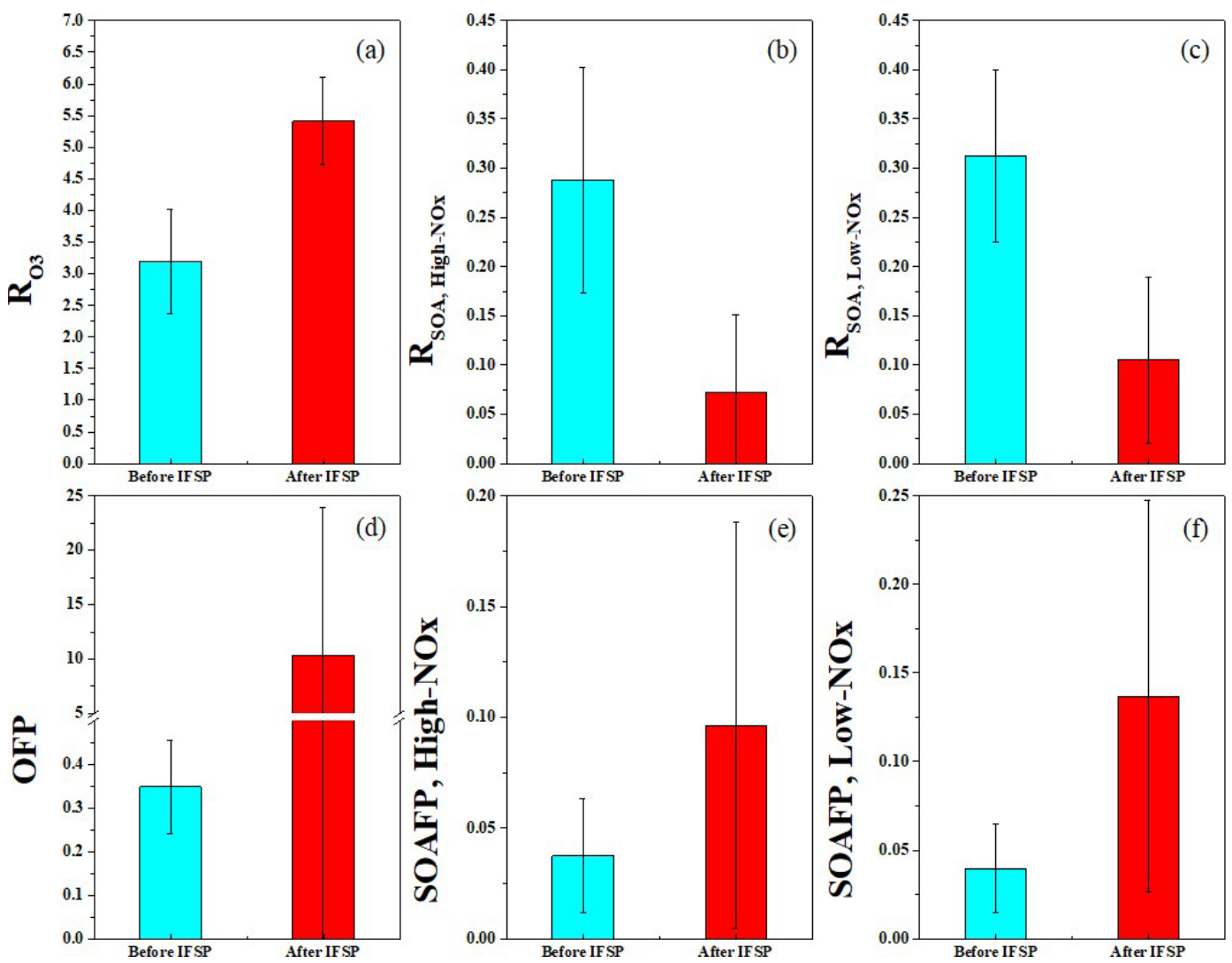

Figure 5. The changes in $R_{3}\left(\mathrm{~g} \mathrm{O}_{3} \mathrm{~g}^{-1} \mathrm{VOCs}\right), R_{\mathrm{SOA}}\left(\mathrm{g} \mathrm{SOA} \mathrm{g}^{-1} \mathrm{VOCs}\right), \mathrm{OFP}\left(\mathrm{g} \mathrm{O}_{3} \mathrm{~kg}^{-1}\right.$ fuel) and SOAFP (g SOA kg $\mathrm{guel}^{-1}$ for coastal vessels before and after IFSP.

$\mathrm{g} \mathrm{O}_{3} \mathrm{~g}^{-1}$ VOCs) and OFP ( $\mathrm{g} \mathrm{O}_{3} \mathrm{~kg}^{-1}$ fuel) were calculated as

$R_{\mathrm{O}_{3}}=\sum_{i} w_{i} \times(\mathrm{MIR})_{i}$,

$\mathrm{OFP}=\sum_{i} \mathrm{EF}_{i} \times(\mathrm{MIR})_{i}$,

where $w_{i}$ is the mass percentage of the total VOC emissions for species $i$.

As described in Fig. 5, the $R_{\mathrm{O}_{3}}$ of the tested coastal vessels increased by almost $70 \%$ from $3.19 \pm 0.82$ to $5.41 \pm$ $0.69 \mathrm{~g} \mathrm{O}_{3} \mathrm{~g}^{-1}$ VOCs. The main reason for the increase in $R_{\mathrm{O}_{3}}$ is that shares of highly reactive alkenes (such as ethylene and propene) increased among the VOCs emitted, and the contribution percentages of alkenes to $R_{\mathrm{O}_{3}}$ increased from $56.4 \% \pm 13.3 \%$ to $75.7 \% \pm 13.3 \%$. OFP increased 28.7 times from $0.35 \pm 0.11$ to $10.37 \pm 13.55 \mathrm{~g} \mathrm{O}_{3} \mathrm{~kg}^{-1}$ fuel.

For the river vessels, their average $R_{\mathrm{O}_{3}}$ was $5.55 \mathrm{~g} \mathrm{O}_{3} \mathrm{~g}^{-1}$ VOCs, which was close to that of the coastal vessels after IFSP, but their average OFP $\left(22.98 \pm 16.59 \mathrm{~g} \mathrm{O}_{3} \mathrm{~kg}^{-1}\right.$ fuel $)$ was more than double that of the coastal vessels. As shown in Fig. S4, the $R_{\mathrm{O}_{3}}\left(4.22 \mathrm{~g} \mathrm{O}_{3} \mathrm{~g}^{-1}\right.$ VOCs) reported by Huang et al. (2018a) for ship emissions after IFSP was approximately $20 \%$ lower than the $R_{\mathrm{O}_{3}}\left(5.41 \mathrm{~g} \mathrm{O}_{3} \mathrm{~g}^{-1}\right.$ VOCs $)$ from this study, and the $R_{\mathrm{O}_{3}}$ of $2.63 \mathrm{O}_{3} \mathrm{~g}^{-1}$ VOCs reported by Xiao et al. (2018) was even lower than the $R_{\mathrm{O}_{3}}$ before IFSP in this study. These results also suggest that there is great diversity in ship-emitted VOCs at berth, even in different regions of China.

\section{SOAFP of the VOCs from ship exhaust}

Similarly, normalized secondary organic aerosols reactivity $\left(R_{\mathrm{SOA}}, \mathrm{g} \mathrm{SOA} \mathrm{g}^{-1} \mathrm{VOCs}\right)$ and SOA formation potential (SOAFP, $\mathrm{g} \mathrm{SOA} \mathrm{kg}^{-1}$ fuel) can also be calculated as the following (Y. L. Zhang et al., 2018):

$R_{\mathrm{SOA}}=\sum_{i} w_{i} \times Y_{i}$

$\mathrm{SOAFP}=\sum_{i} \mathrm{EF}_{i} \times Y_{i}$,

where $Y_{i}$ is the SOA yield of VOC species $i$. We could calculate the SOAFP under high- $\mathrm{NO}_{x}$ and low- $\mathrm{NO}_{x}$ conditions (Ng et al., 2007), but we should be cautious in interpreting the results because intermediate volatile organic compounds were not measured in this study, which may lead to underestimation of SOA yields (Huang et al., 2018b; Lou et al., 2019).

As shown in Fig. 5, for the coastal vessels, $R_{\mathrm{SOA}}$ decreased by $\sim 75 \%$ from $0.288 \pm 0.114$ to $0.073 \pm$ $0.079 \mathrm{~g} \mathrm{SOA} \mathrm{g}^{-1}$ VOCs under high- $\mathrm{NO}_{x}$ conditions, while $R_{\text {SOA }}$ also decreased by $66.5 \%$ from $0.313 \pm 0.088$ to $0.105 \pm$ $0.085 \mathrm{~g} \mathrm{SOA} \mathrm{g}^{-1}$ VOCs under low-NO $\mathrm{NO}_{x}$ conditions. This de- 
cline of $R_{\mathrm{SOA}}$ resulted from the decrease in mass percentages of aromatics and alkanes, which have higher SOA yields than those of alkenes ( $\mathrm{Ng}$ et al., 2007; Lim and Ziemann, 2009; Loza et al., 2014). However, with the dramatically increased EFs of the VOCs, under high- $\mathrm{NO}_{x}$ conditions, SOAFP increased 1.6 times from $0.037 \pm 0.026$ to $0.096 \pm 0.092 \mathrm{~g} \mathrm{SOA} \mathrm{kg}^{-1}$ fuel, and under low- $\mathrm{NO}_{x}$ conditions, SOAFP increased 2.5 times from $0.040 \pm 0.025$ to $0.137 \pm 0.111 \mathrm{~g} \mathrm{SOA} \mathrm{kg}^{-1}$ fuel.

In particular, the $R_{\mathrm{SOA}}$ for ship F (Fig. S4) was significantly higher than that of the other ships, largely due to a higher fraction $(11.5 \%)$ of $n$-dodecane, which had the highest SOA yield among the VOCs. For the river vessels, the $R_{\mathrm{SOA}}$ was the lowest in the test ships, with a value of $0.037 \pm 0.017 \mathrm{~g} \mathrm{SOA} \mathrm{g}^{-1}$ VOCs under high-NO conditions and $0.069 \pm 0.026 \mathrm{~g} \mathrm{SOA} \mathrm{g}^{-1}$ VOCs under low$\mathrm{NO}_{x}$ conditions. However, their SOAFP was $0.165 \pm 0.131 \mathrm{~g}$ SOA kg-1 fuel under high- $\mathrm{NO}_{x}$ conditions and $0.322 \pm$ $0.267 \mathrm{~g} \mathrm{SOA} \mathrm{kg}^{-1}$ fuel under low- $\mathrm{NO}_{x}$ conditions, which were the largest of the values due to their much higher EFs.

As shown in Fig. S4, based on the VOC emissions from ships at berth reported in Huang et al. (2018a), we calculated a $R_{\mathrm{SOA}}$ of $0.080 \mathrm{~g} \mathrm{SOA} \mathrm{g}^{-1}$ VOCs under high- $\mathrm{NO}_{x}$ conditions and $0.228 \mathrm{~g} \mathrm{SOA} \mathrm{g}^{-1}$ VOCs under low- $\mathrm{NO}_{x}$ conditions for coastal vessels also using low-sulfur fuels. This relatively higher $R_{\text {SOA }}$ under low- $\mathrm{NO}_{x}$ conditions was related to the higher fractions of aromatics in the VOC emissions. Using another method in Gentner et al. (2012), Xiao et al. (2018) reported an average $R_{\mathrm{SOA}}$ of $0.017 \mathrm{~g} \mathrm{SOA} \mathrm{g}^{-1}$ VOCs under high- $\mathrm{NO}_{x}$ conditions, which was close to a $R_{\mathrm{SOA}}$ of $0.015 \mathrm{~g} \mathrm{SOA} \mathrm{g}^{-1}$ VOCs calculated by the same method for the coastal vessels after IFSP.

\section{Conclusions}

Ship emissions control is primarily targeted in terms of PMrelated pollution, and designating an ECA with a fuel switch policy is a widely adopted approach to control air pollution in harbor cities. In the present study, we measured emissions from coastal vessels at berth in the Port of Guangzhou in the PRD region, one of the three newly established ECAs since 2017; we preliminarily investigated the changes in emissions caused by the fuel switch policy, and we further compared the results with those measured for river vessels unaffected by the fuel switch policy.

As reported by previous studies, our study also demonstrated that after IFSP, the EFs of both $\mathrm{SO}_{2}$ and $\mathrm{PM}_{2.5}$ for the coastal vessels decreased, as evidenced by the fact that the EFs of $\mathrm{SO}_{2}$ reduced by $\sim 78.0 \%$ and the EFs of $\mathrm{PM}_{2.5}$ reduced by $\sim 55.5 \%$ on average. However, the EF of the VOCs increased approximately 14 fold from $118 \pm 56.1$ to $1807 \pm 1746 \mathrm{mg} \mathrm{kg}^{-1}$. Moreover, the compositions of the VOCs emitted from the coastal vessels also changed greatly. The mass percentages of alkenes increased from $8.5 \%-$
$27.3 \%$ to $44.4 \%-86.6 \%$. The sharp increase in the EFs, as well as elevated fractions of the more reactive species, resulted in a much higher OFP for the VOCs than that of the other species, which sharply increased approximately 29 fold from $0.35 \pm 0.11$ to $10.37 \pm 13.55 \mathrm{~g} \mathrm{O}_{3} \mathrm{~kg}^{-1}$ fuel. The SOAFP also increased by over $50 \%$, although the $R_{\mathrm{SOA}}$ was reduced by $66.5 \%-74.8 \%$.

For the river vessels, which were not affected by the fuel switch policy, the EFs of the VOCs were measured at values as high as $3358 \pm 2771 \mathrm{mg} \mathrm{kg}^{-1}$, which was almost double those for the coastal vessels after IFSP, with the OFP and SOAFP also at approximately 2 times their counterparts for the coastal vessels after IFSP.

In summary, our tests in the Port of Guangzhou demonstrated that for coastal vessels at berth, the fuel switch from high-sulfur residual fuel oil to low-sulfur diesel or heavy oil resulted in substantially decreased emissions of $\mathrm{SO}_{2}$ and $\mathrm{PM}_{2.5}$ and therefore would benefit PM pollution control. However, the fuel switch policy raised another concern due to the dramatic increase in emissions of reactive VOCs from the coastal vessels. This phenomenon was also reinforced by the fact that river vessels, which had used diesel oils the entire time and thus were not affected by the fuel switch policy, also had high emissions of reactive VOCs. This high level of emissions of reactive VOCs is a concern and will probably worsen ozone pollution and SOA formation in harbor cities; further lowering of the emissions of reactive VOCs from ocean-going, coastal and river vessels is another regulatory and technological concern.

Data availability. The data used in this publication are available to the community, and they can be accessed by request to the corresponding author.

Supplement. The supplement related to this article is available online at: https://doi.org/10.5194/acp-20-1887-2020-supplement.

Author contributions. $\mathrm{YZ}$ and $\mathrm{XW}$ designed the research. $\mathrm{ZW}, \mathrm{YZ}$ and XW wrote the paper. JH, XH, XY and WY helped with sampling. $\mathrm{HC}$ and $\mathrm{YW}$ helped with project coordination and data interpretation. RZ, MZ, HF and ZZ helped with sample analysis.

Competing interests. The authors declare that they have no conflict of interest.

Acknowledgements. The authors would like to thank all the students and people from the Guangzhou Environmental Monitoring Center who helped with sample collection. 
Financial support. This study was supported by the National Key Research and Development Program (2016YFC0202204/2017YFC0212802), Natural Science Foundation of China (41571130031/41530641/41673116), Youth Innovation Promotion Association, CAS (2017406), the Chinese Academy of Sciences (QYZDJ-SSW-DQC032), Guangdong Science and Technology Department (2017BT01Z134/2016TQ03Z993), and Guangdong Foundation for Program of Science and Technology Research (2017B030314057).

Review statement. This paper was edited by Alex Lee and reviewed by two anonymous referees.

\section{References}

Agrawal, H., Welch, W. A., Miller, J. W., and Cocker, D. R.: Emission measurements from a crude oil tanker at sea, Environ. Sci. Technol., 42, 7098-7103, https://doi.org/10.1021/es703102y, 2008.

Agrawal, H., Eden, R., Zhang, X. Q., Fine, P. M., Katzenstein, A., Miller, J. W., Ospital, J., Teffera, S., and Cocker, D. R.: Primary particulate matter from ocean-going engines in the southern California air basin, Environ. Sci. Technol., 43, 5398-5402, https://doi.org/10.1021/es8035016, 2009.

Agrawal, H., Welch, W. A., Henningsen, S., Miller, J. W., and Cocker III, D. R.: Emissions from main propulsion engine on container ship at sea, J. Geophys. Res.-Atmos., 115, D23205, https://doi.org/10.1029/2009JD013346, 2010.

Atkinson, R.: Atmospheric chemistry of VOCs and $\mathrm{NO}_{x}$, Atmos. Environ., 34, 2063-2101, https://doi.org/10.1016/s13522310(99)00460-4, 2000.

Carter, W. P. L.: Update maximum incremental reactivity scale and hydrocarbon bin reactivities for regulatory application, California Air Resources Board Contract 07-339, 2009.

Chameides, W. L., Fehsenfeld, F., Rodgers, M. O., Cardelino, C., Martinez, J., Parrish, D., Lonneman, W., Lawson, D. R., Rasmussen, R. A., Zimmerman, P., Greenberg, J., Middleton, P., and Wang, T.: Ozone precursor relationships in the ambient atmosphere, J. Geophys. Res.-Atmos., 97, 6037-6055, https://doi.org/10.1029/91jd03014, 1992.

China Port Press: China ports yearbook 2018, China, 2018 (in Chinese).

Contini, D., Gambaro, A., Donateo, A., Cescon, P., Cesari, D., Merico, E., Belosi, F., and Citron, M.: Inter-annual trend of the primary contribution of ship emissions to $\mathrm{PM}_{2.5}$ concentrations in Venice (Italy): Efficiency of emissions mitigation strategies, Atmos. Environ., 102, 183-190, https://doi.org/10.1016/j.atmosenv.2014.11.065, 2015.

Cooper, D. A.: Exhaust emissions from ships at berth, Atmos. Environ., 37, 3817-3830, https://doi.org/10.1016/S13522310(03)00446-1, 2003.

Cooper, D. A., Peterson, K., and Simpson, D.: Hydrocarbon, PAH and PCB emissions from ferries: A case study in the Skagerak-Kattegatt-Oresund region, Atmos. Environ., 30, 2463 2473, https://doi.org/10.1016/1352-2310(95)00494-7, 1996.

Corbett, J. J. and Fischbeck, P.: Emissions from ships, Science, 278, 823-824, https://doi.org/10.1126/science.278.5339.823, 1997.
Corbett, J. J., Fischbeck, P. S., and Pandis, S. N.: Global nitrogen and sulfur inventories for oceangoing ships, J. Geophys. Res.Atmos., 104, 3457-3470, https://doi.org/10.1029/1998jd100040, 1999.

Corbett, J. J., Winebrake, J. J., Green, E. H., Kasibhatla, P., Eyring, V., and Lauer, A.: Mortality from ship emissions: A global assessment, Environ. Sci. Technol., 41, 8512-8518, https://doi.org/10.1021/es071686z, 2007.

Feng, J., Zhang, Y., Li, S., Mao, J., Patton, A. P., Zhou, Y., Ma, W., Liu, C., Kan, H., Huang, C., An, J., Li, L., Shen, Y., Fu, Q., Wang, X., Liu, J., Wang, S., Ding, D., Cheng, J., Ge, W., Zhu, H., and Walker, K.: The influence of spatiality on shipping emissions, air quality and potential human exposure in the Yangtze River Delta/Shanghai, China, Atmos. Chem. Phys., 19, 61676183, https://doi.org/10.5194/acp-19-6167-2019, 2019.

Fu, M. L., Ding, Y., Ge, Y. S., Yu, L. X., Yin, H., Ye, W. T., and Liang, B.: Real-world emissions of inland ships on the Grand Canal, China, Atmos. Environ., 81, 222-229, https://doi.org/10.1016/j.atmosenv.2013.08.046, 2013.

Fu, M. L., Liu, H., Jin, X. X., and He, K. B.: National- to port-level inventories of shipping emissions in China, Environ. Res. Lett., 12, 114024, https://doi.org/10.1088/1748-9326/aa897a, 2017.

Gentner, D. R., Isaacman, G., Worton, D. R., Chan, A. W. H., Dallmann, T. R., Davis, L., Liu, S., Day, D. A., Russell, L. M., Wilson, K. R., Weber, R., Guha, A., Harley, R. A., and Goldstein, A. H.: Elucidating secondary organic aerosol from diesel and gasoline vehicles through detailed characterization of organic carbon emissions, P. Natl. Acad. Sci. USA, 109, 18318-18323, https://doi.org/10.1073/pnas.1212272109, 2012.

Huang, C., Hu, Q. Y., Wang, H. Y., Qiao, L. P., Jing, S. A., Wang, H. L., Zhou, M., Zhu, S. H., Ma, Y. G., Lou, S. R., Li, L., Tao, S. K., Li, Y. J., and Lou, D. M.: Emission factors of particulate and gaseous compounds from a large cargo vessel operated under real-world conditions, Environ. Pollut., 242, 667-674, https://doi.org/10.1016/j.envpol.2018.07.036, 2018a.

Huang, C., Hu, Q. Y., Li, Y. J., Tian, J. J., Ma, Y. G., Zhao, Y. L., Feng, J. L., An, J. Y., Qiao, L. P., Wang, H. L., Jing, S. A., Huang, D. D., Lou, S. R., Zhou, M., Zhu, S. H., Tao, S. K., and Li, L.: Intermediate volatility organic compound emissions from a large cargo vessel operated under realworld conditions, Environ. Sci. Technol., 52, 12934-12942, https://doi.org/10.1021/acs.est.8b04418, 2018b.

IMO: Emission Control Areas (ECAs) Designated Under MARPOL Annex VI, available at: http://www.imo.org/en/OurWork/Environment/PollutionPrevention (last access: 27 October 2019), 2017.

Kotchenruther, R. A.: The effects of marine vessel fuel sulfur regulations on ambient $\mathrm{PM}_{2.5}$ at coastal and near coastal monitoring sites in the US, Atmos. Environ., 151, 52-61, https://doi.org/10.1016/j.atmosenv.2016.12.012, 2017.

Lack, D. A., Cappa, C. D., Langridge, J., Bahreini, R., Buffaloe, G., Brock, C., Cerully, K., Coffman, D., Hayden, K., Holloway, J., Lerner, B., Massoli, P., Li, S.-M., McLaren, R., Middlebrook, A. M., Moore, R., Nenes, A., Nuaaman, I., Onasch, T. B., Peischl, J., Perring, A., Quinn, P. K., Ryerson, T., Schwartz, J. P., Spackman, R., Wofsy, S. C., Worsnop, D., Xiang, B., and Williams, E.: Impact of fuel quality regulation and speed reductions on shipping emissions: implications for cli- 
mate and air quality, Environ. Sci. Technol., 45, 9052-9060, https://doi.org/10.1021/es2013424, 2011.

Li, C., Yuan, Z. B., Ou, J. M., Fan, X. L., Ye, S. Q., Xiao, T., Shi, Y. Q., Huang, Z. J., Ng, S. K. W., Zhong, Z. M., and Zheng, J. Y.: An AIS-based high-resolution ship emission inventory and its uncertainty in Pearl River Delta region, China, Sci. Total Environ., 573, 1-10, https://doi.org/10.1016/j.scitotenv.2016.07.219, 2016.

Li, G. H., Zhang, Y. L., Fu, X. X., Li, Z. Y., Huang, Z. H., and Wang, X. M.: Sulfur contents in commercial available gasoline and diesel oils sold in 8 Chinese cities, Environ. Sci. Technol., 39, 373-377, 2016 (in Chinese).

Li, S., Zhu, M., Yang, W. Q., Tang, M. J., Huang, X. L., Yu, Y. G., Fang, H., Yu, X., Yu, Q. Q., Fu, X. X., Song, W., Zhang, Y. L., Bi, X. H., and Wang, X. M.: Filter-based measurement of light absorption by brown carbon in $\mathrm{PM}_{2.5}$ in a megacity in South China, Sci. Total Environ., 633, 1360-1369, https://doi.org/10.1016/j.scitotenv.2018.03.235, 2018.

Lim, Y. B. and Ziemann, P. J.: Effects of molecular structure on aerosol yields from $\mathrm{OH}$ radical-initiated reactions of linear, branched, and cyclic alkanes in the presence of $\mathrm{NO}_{x}$, Environ. Sci. Technol., 43, 2328-2334, https://doi.org/10.1021/es803389s, 2009.

Liu, H., Jin, X. X., Wu, L. L., Wang, X. M., Fu, M. L., Lv, Z. F., Morawska, L., Huang, F. F., and He, K. B.: The impact of marine shipping and its DECA control on air quality in the Pearl River Delta, China, Sci. Total Environ., 625, 1476-1485, https://doi.org/10.1016/j.scitotenv.2018.01.033, 2018.

Liu, T., Wang, X., Deng, W., Hu, Q., Ding, X., Zhang, Y., He, Q., Zhang, Z., Lü, S., Bi, X., Chen, J., and Yu, J.: Secondary organic aerosol formation from photochemical aging of lightduty gasoline vehicle exhausts in a smog chamber, Atmos. Chem. Phys., 15, 9049-9062, https://doi.org/10.5194/acp-159049-2015, 2015.

Liu, T. Y., Wang, X. M., Wang, B. G., Ding, X., Deng, W., Lv, S. J., and Zhang, Y. L.: Emission factor of ammonia $\left(\mathrm{NH}_{3}\right)$ from on-road vehicles in China: tunnel tests in urban Guangzhou, Environ. Res. Lett., 9, 064027, https://doi.org/10.1088/17489326/9/6/064027, 2014.

Lou, H. J., Hao, Y. J., Zhang, W. W., Su, P. H., Zhang, F., Chen, Y. J., Feng, D. L., and Li, Y. F.: Emission of intermediate volatility organic compounds from a ship main engine burning heavy fuel oil, J. Environ. Sci., 84, 197-204, https://doi.org/10.1016/j.jes.2019.04.029, 2019.

Loza, C. L., Craven, J. S., Yee, L. D., Coggon, M. M., Schwantes, R. H., Shiraiwa, M., Zhang, X., Schilling, K. A., Ng, N. L., Canagaratna, M. R., Ziemann, P. J., Flagan, R. C., and Seinfeld, J. H.: Secondary organic aerosol yields of 12-carbon alkanes, Atmos. Chem. Phys., 14, 1423-1439, https://doi.org/10.5194/acp14-1423-2014, 2014.

Lv, Z., Liu, H., Ying, Q., Fu, M., Meng, Z., Wang, Y., Wei, W., Gong, H., and He, K.: Impacts of shipping emissions on $\mathrm{PM}_{2.5}$ pollution in China, Atmos. Chem. Phys., 18, 15811-15824, https://doi.org/10.5194/acp-18-15811-2018, 2018.

Matthias, V., Bewersdorff, I., Aulinger, A., and Quante, M.: The contribution of ship emissions to air pollution in the North Sea regions, Environ. Pollut., 158, 2241-2250, https://doi.org/10.1016/j.envpol.2010.02.013, 2010.
Murphy, S. M., Agrawal, H., Sorooshian, A., Padro, L. T., Gates, H., Hersey, S., Welch, W. A., Jung, H., Miller, J. W., Cocker III, D. R., Nenes, A., Jonsson, H. H., Flagan, R. C., and Seinfeld, J. H.: Comprehensive simultaneous shipboard and airborne characterization of exhaust from a modern container ship at sea, Environ. Sci. Technol., 43, 4626-4640, https://doi.org/10.1021/es802413j, 2009.

Ng, N. L., Kroll, J. H., Chan, A. W. H., Chhabra, P. S., Flagan, R. C., and Seinfeld, J. H.: Secondary organic aerosol formation from $m$-xylene, toluene, and benzene, Atmos. Chem. Phys., 7, 3909-3922, https://doi.org/10.5194/acp-7-3909-2007, 2007.

O’Dowd, C. D., Aalto, P., Hameri, K., Kulmala, M., and Hoffmann, T.: Aerosol formation - Atmospheric particles from organic vapours, Nature, 416, 497-498, https://doi.org/10.1038/416497a, 2002.

Odum, J. R., Jungkamp, T. P. W., Griffin, R. J., Flagan, R. C., and Seinfeld, J. H.: The atmospheric aerosol-forming potential of whole gasoline vapor, Science, 276, 96-99, https://doi.org/10.1126/science.276.5309.96, 1997.

Peng, Z. H., Ge, Y. S., Tan, J. W., Fu, M. L., Wang, X., Chen, M., Yin, H., and Ji, Z.: Emissions from several in-use ships tested by portable emission measurement system, Ocean Eng., 116, 260267, https://doi.org/10.1016/j.oceaneng.2016.02.035, 2016.

Perez, N., Pey, J., Reche, C., Cortes, J., Alastuey, A., and Querol, $\mathrm{X}$.: Impact of harbour emissions on ambient $\mathrm{PM}_{10}$ and $\mathrm{PM}_{2.5}$ in Barcelona (Spain): evidences of secondary aerosol formation within the urban area, Sci. Total Environ., 571, 237-250, https://doi.org/10.1016/j.scitotenv.2016.07.025, 2016.

Pey, J., Perez, N., Cortes, J., Alastuey, A., and Querol, X.: Chemical fingerprint and impact of shipping emissions over a western Mediterranean metropolis: primary and aged contributions, Sci. Total Environ., 463, 497-507, https://doi.org/10.1016/j.scitotenv.2013.06.061, 2013.

Ramacher, M. O. P., Karl, M., Bieser, J., Jalkanen, J.-P., and Johansson, L.: Urban population exposure to $\mathrm{NO}_{x}$ emissions from local shipping in three Baltic Sea harbour cities - a generic approach, Atmos. Chem. Phys., 19, 9153-9179, https://doi.org/10.5194/acp-19-9153-2019, 2019.

Song, S.-K., Shon, Z.-H., Kim, Y.-K., Kang, Y.-H., Oh, I.-B., and Jung, C.-H.: Influence of ship emissions on ozone concentrations around coastal areas during summer season, Atmos. Environ., 44, 713-723, https://doi.org/10.1016/j.atmosenv.2009.11.010, 2010.

Standards Press of China: National standard of the People's Republic of China: general diesel fuels (GB 252-2015), China, 2015 (in Chinese).

Tagaris, E., Stergiou, I., and Sotiropoulou, R. E. P.: Impact of shipping emissions on ozone levels over Europe: assessing the relative importance of the Standard Nomenclature for Air Pollution (SNAP) categories, Environ. Sci. Pollut. R., 24, 14903-14909, https://doi.org/10.1007/s11356-017-9046-x, 2017.

Tao, J., Zhang, L. M., Cao, J. J., Zhong, L. J., Chen, D. S., Yang, Y. H., Chen, D. H., Chen, L. G., Zhang, Z. S., Wu, Y. F., Xia, Y. J., Ye, S. Q., and Zhang, R. J.: Source apportionment of $\mathrm{PM}_{2.5}$ at urban and suburban areas of the Pearl River Delta region, south China - with emphasis on ship emissions, Sci. Total Environ., 574, 1559-1570, https://doi.org/10.1016/j.scitotenv.2016.08.175, 2017.

Tao, L., Fairley, D., Kleeman, M. J., and Harley, R. A.: Effects of switching to lower sulfur marine fuel oil on air quality in the San 
Francisco Bay area, Environ. Sci. Technol., 47, 10171-10178, https://doi.org/10.1021/es401049x, 2013.

UNCTAD: Review of Maritime Transport, United Nations Publication, The United States, p. 6, 2016.

Viana, M., Fann, N., Tobias, A., Querol, X., Rojas-Rueda, D., Plaza, A., Aynos, G., Conde, J. A., Fernandez, L., and Fernandez, C.: Environmental and health benefits from designating the Marmara Sea and the Turkish Straits as an emission control area (ECA), Environ. Sci. Technol., 49, 3304-3313, https://doi.org/10.1021/es5049946, 2015.

Wang, R. N., Tie, X. X., Li, G. H., Zhao, S. Y., Long, X., Johansson, L., and An, Z. S.: Effect of ship emissions on $\mathrm{O}_{3}$ in the Yangtze River Delta region of China: Analysis of WRF-Chem modeling, Sci. Total Environ., 683, 360-370, https://doi.org/10.1016/j.scitotenv.2019.04.240, 2019.

Wang, X., Shen, Y., Lin, Y., Pan, J., Zhang, Y., Louie, P. K. K., Li, M., and Fu, Q.: Atmospheric pollution from ships and its impact on local air quality at a port site in Shanghai, Atmos. Chem. Phys., 19, 6315-6330, https://doi.org/10.5194/acp19-6315-2019, 2019.

Xiao, Q., Li, M., Liu, H., Fu, M., Deng, F., Lv, Z., Man, H., Jin, X., Liu, S., and He, K.: Characteristics of marine shipping emissions at berth: profiles for particulate matter and volatile organic compounds, Atmos. Chem. Phys., 18, 95279545, https://doi.org/10.5194/acp-18-9527-2018, 2018.

Yang, W., Zhang, Y., Wang, X., Li, S., Zhu, M., Yu, Q., Li, G., Huang, Z., Zhang, H., Wu, Z., Song, W., Tan, J., and Shao, M.: Volatile organic compounds at a rural site in Beijing: influence of temporary emission control and wintertime heating, Atmos. Chem. Phys., 18, 12663-12682, https://doi.org/10.5194/acp-1812663-2018, 2018.

Yu, Q. Q., Yang, W. Q., Zhu, M., Gao, B., Li, S., Li, G. H., Fang, H., Zhou, H. S., Zhang, H. N., Wu, Z. F., Song, W., Tan, J. H., Zhang, Y. L., Bi, X. H., Chen, L. G., and Wang, X. M.: Ambient PM2.5-bound polycyclic aromatic hydrocarbons (PAHs) in rural Beijing: Unabated with enhanced temporary emission control during the 2014 APEC summit and largely aggravated after the start of wintertime heating, Environ. Pollut., 238, 532-542, https://doi.org/10.1016/j.envpol.2018.03.079, 2018.

Zetterdahl, M., Moldanova, J., Pei, X. Y., Pathak, R. K., and Demirdjian, B.: Impact of the $0.1 \%$ fuel sulfur content limit in SECA on particle and gaseous emissions from marine vessels, Atmos. Environ., 145, 338-345, https://doi.org/10.1016/j.atmosenv.2016.09.022, 2016.
Zhang, F., Chen, Y., Tian, C., Lou, D., Li, J., Zhang, G., and Matthias, V.: Emission factors for gaseous and particulate pollutants from offshore diesel engine vessels in China, Atmos. Chem. Phys., 16, 6319-6334, https://doi.org/10.5194/acp-166319-2016, 2016.

Zhang, F., Chen, Y. J., Chen, Q., Feng, Y. L., Shang, Y., Yang, X., Gao, H. W., Tian, C. G., Li, J., Zhang, G., Matthias, V., and Xie, Z. Y.: Real-world emission factors of gaseous and particulate pollutants from marine fishing boats and their total emissions in China, Environ. Sci. Technol., 52, 4910-4919, https://doi.org/10.1021/acs.est.7b04002, 2018.

Zhang, Y., Deng, F., Man, H., Fu, M., Lv, Z., Xiao, Q., Jin, X., Liu, S., He, K., and Liu, H.: Compliance and port air quality features with respect to ship fuel switching regulation: a field observation campaign, SEISO-Bohai, Atmos. Chem. Phys., 19, 4899-4916, https://doi.org/10.5194/acp-19-4899-2019, 2019.

Zhang, Y. L., Wang, X. M., Barletta, B., Simpson, I. J., Blake, D. R., Fu, X. X., Zhang, Z., He, Q. F., Liu, T. Y., Zhao, X. Y., and Ding, X.: Source attributions of hazardous aromatic hydrocarbons in urban, suburban and rural areas in the Pearl River Delta (PRD) region, J. Hazard. Mater., 250, 403-411, https://doi.org/10.1016/j.jhazmat.2013.02.023, 2013.

Zhang, Y. L., Wang, X. M., Zhang, Z., Lv, S. J., Huang, Z. H., and Li, L. F.: Sources of C-2-C-4 alkenes, the most important ozone nonmethane hydrocarbon precursors in the Pearl River Delta region, Sci. Total Environ., 502, 236-245, https://doi.org/10.1016/j.scitotenv.2014.09.024, 2015.

Zhang, Y. L., Yang, W. Q., Simpson, I., Huang, X. Y., Yu, J. Z., Huang, Z. H., Wang, Z. Y., Zhang, Z., Liu, D., Huang, Z. Z., Wang, Y. J., Pei, C. L., Shao, M., Blake, D. R., Zheng, J. Y., Huang, Z. J., and Wang, X. M.: Decadal changes in emissions of volatile organic compounds (VOCs) from on-road vehicles with intensified automobile pollution control: Case study in a busy urban tunnel in south China, Environ. Pollut., 233, 806819, https://doi.org/10.1016/j.envpol.2017.10.133, 2018. 